\title{
Geographic distribution of economic potential of agricultural and forest biomass residual for energy use: Case study Croatia
}

\author{
Boris Ćosić $^{\mathrm{a}, *}$, Zoran Stanić ${ }^{\mathrm{b}}$, Neven Duić ${ }^{\mathrm{a}}$ \\ ${ }^{a}$ Department of Energy, Power Engineering and Environment, Faculty of Mechanical Engineering and Naval Architecture, University of Zagreb, Ivana Lučića 5, \\ 10002 Zagreb, Croatia \\ ${ }^{\mathrm{b}}$ HEP - Obnovljivi izvori energije d.o.o., Ulica grada Vukovara 37, 10000 Zagreb, Croatia
}

\section{A R T I C L E I N F O}

\section{Article history:}

Received 8 March 2010

Received in revised form 28 August 2010

Accepted 6 October 2010

Available online 7 December 2010

\section{Keywords:}

Biomass

Forestry residues

Wheat straw

Corn stover

Energy potential

\begin{abstract}
A B S T R A C T
This paper provides methodology for regional analysis of biomass energy potential and for assessing the cost of the biomass at the power plant (PP) location considering transport distance, transport costs and size of the power plants. Also, methodology for determination of an upper-level price of the biomass which energy plant can pay to the external suppliers has been proposed. The methodology was applied on the case of Croatia and energy potential of biomass in the Croatian counties was calculated, using different methodologies, for wheat straw, corn stover and forestry residues, types of biomass considered economically viable at the moment. Results indicate that the average energy potential of wheat straw is 8.5 PJ, corn stover 7.2 PJ and forestry residues 5.9 PJ.
\end{abstract}

(c) 2010 Elsevier Ltd. All rights reserved.

\section{Introduction}

In order to reduce greenhouse gas (GHG) emissions, increase domestic industry development, secure and diversify the supply of energy, biomass as a renewable energy resource plays an important role for reaching these goals in the industrial countries [1-7]. Because of its widespread non-commercial use, biomass is covering more than $10 \%$ of the total world primary energy supply of $479 \mathrm{EJ}$ [8]. Compared to other renewable energy sources biomass has the ability to store feedstock and use it when it is required [9]. Due to diversity of biomass residues and different products that can be obtained, there are several processes that allow transforming biomass in high energy fuels that are easy to transport and handle $[10,11]$. Furthermore, using biomass for production of energy can significantly contribute to the job creation and economic development of rural economies and slow down migrations from these areas to cities [12-17]. Because of that, detailed and accurate estimation of the different biomass resources and their energy potential is needed.

\footnotetext{
* Corresponding author. Tel.: +385 1616 8242; fax: +385 16156940.

E-mail addresses: boris.cosic@fsb.hr (B. Ćosić), zoran.stanic@hep.hr (Z. Stanić), neven.duic@fsb.hr (N. Duić).

URL: http://www.powerlab.fsb.hr/bcosic, http://www.powerlab.fsb.hr/neven
}

A number of studies for estimating the potential of agricultural [18-21] and forestry residues [22-25] based on the yield, forest area, residues coefficient (i.e., straw to grain ratio), and availability factors (i.e., mechanisation losses, fraction of the residue that can't be removed from the area) have been published. Potential of agricultural and forestry residues in those studies was calculated for the regions [26-28], countries [29-32] or worldwide [33,34] and in the most cases, geographic information system (GIS) has been used to calculate the potential of agricultural and forestry residues $[35,36]$. In order to provide fast and precise assessment of the potential, regional distribution and economic performance of the biomass, based on the location which is the key factor for the economic viability and environmental performance, the new methodology has been proposed. Because economic benefit is the major incentive for selection of the energy plant location and biomass fuels, this paper focuses on the competitive advantage of the agricultural and forestry residues in relation to energy plant location in order to increase understanding which part of the resource base is economically attractive for use in energy plants.

In the case of the biomass feedstock, the greater the output of the plant, the greater the biomass required and the greater the average distance required to transport the biomass [37]. At the end all this results with the increase of the energy plants fuel costs and electricity generation costs. These costs can be minimised by 
Table 1

Characteristics of different types of biomass [48-55].

\begin{tabular}{|c|c|c|c|c|}
\hline & & Wheat straw & Corn stover & Forest residual \\
\hline Straw (stover) to grain ratio $[-]$ & & $0.9-1.6$ & $0.68-1.07$ & - \\
\hline \multirow[t]{2}{*}{ Straw cover required for soil protection [t/ha] } & Wind erosion & $1.0-2.0$ & - & - \\
\hline & Water erosion & $0.5-$ continues grass & - & - \\
\hline Biomass for livestock production [t/cattle] & & $0.5-1.0$ & - & - \\
\hline Mechanisation losses in the collecting process [\%] & & - & $20-30$ & - \\
\hline Soil protection factor [\%] & & - & $30-60$ & - \\
\hline Forest residue factor [\%] & & - & - & $12-20$ \\
\hline $\mathrm{LHV}[\mathrm{GJ} / \mathrm{t}]$ & & $13.74-17.86$ & $11.5-15.3$ & $15.06-5.34$ \\
\hline Humidity of biomass [\%] & & $20-100$ & $30-15$ & $10-60$ \\
\hline
\end{tabular}

optimal utilisation of the vehicle payload, by optimal location and size of the energy plant and by choice of the shortest travel paths [38-42].

This paper focuses on the identification and quantification of the available biomass in the regions and analysis of the biomass costs at the power plant locations. Firstly, methodology for assessment of regional biomass potential and the cost of the biomass at the plant location was developed. Also a model for the determination of an upper-level price for the biomass which energy plant can pay to the external suppliers is proposed. Secondly, the characteristics of the case study area have been elaborated and the results of the assessment and economic analysis are presented.

\section{Methodology}

In order to provide a comprehensive overview on the domestic potential of the biomass for different regions, the study aimed to investigate all economically viable biomass resources based on the region needs and applicable technology. To select all economically viable biomass resource the RenewIslands/ADEG methodology has been used. This methodology was firstly developed for use on the islands $[43,44]$ but during time, it has been upgraded for use in other regions [45], in ADEG project $[46,47]$. A very detailed description of RenewIslands methodology has been given in [43] and RenewIslands/ADEG methodology in [44]. Using this methodology three types of biomass were selected for further analysis, based on the region needs, its resources and the applicable technology. Selected biomass types are:

- Biomass from wheat straw

- Biomass from corn stover

- Biomass from forestry residues

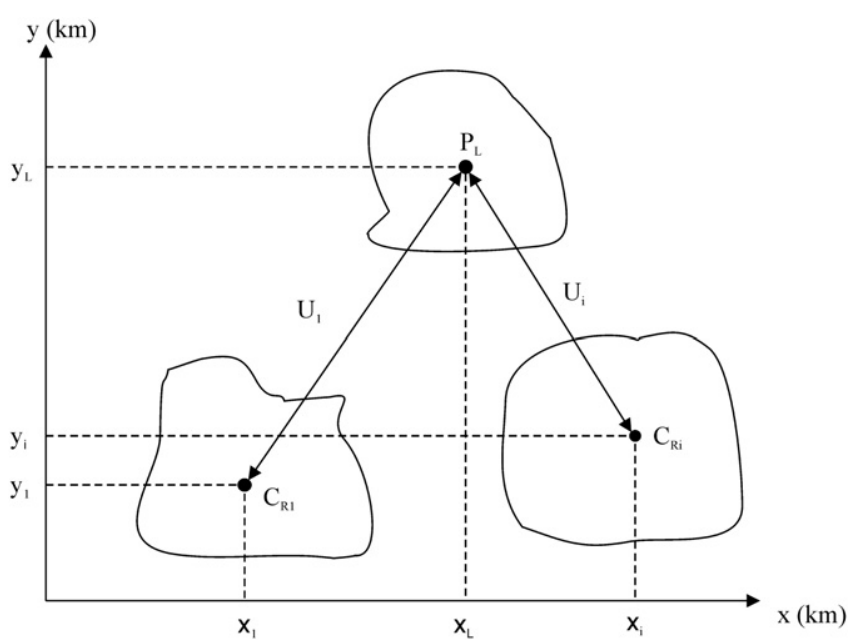

Fig. 1. Visual representation of the optimal transport distance methodology.

\subsection{Technical available potential of biomass}

The total potential of biomass is defined as the total annual production of agricultural and forestry residues in the regions. The total potential of biomass cannot be utilized as an energy source, because the part of the residuals needs to be left on the field for soil protection, feeding and bedding of animals and because of mechanisation losses during collecting and transportation process. Technical available potential of biomass for energy purpose is determined by subtracting quantities of residuals needed for soil protection, animal feeding and bedding from the total production of each biomass residue.

\subsubsection{Agricultural residual - wheat straw}

Wheat straw is an agricultural residual that remains on the soil surface after grain harvest. The amount of the residue produced on the field varies considerably with growing conditions and the amount of crop grown. Total quantity of this residual, generated during the grain harvest, is not possible to find in statistic yearbook and because of that total production of the wheat straw in the regions $i$ (expressed in $\mathrm{t}$ ) will be obtained as:

$T_{\mathrm{WS}(i)}=W_{\mathrm{P}(i)} \times \mathrm{STGR}_{\mathrm{W}(i)}$

where $W_{\mathrm{P}(i)}$ represents the wheat production in region $i(\mathrm{t})$ and $\mathrm{STGR}_{\mathrm{W}(i)}$ the wheat straw to grain ratio, which depends on the type of wheat, time of wheat seeding, cultivation of soil and total amount of nitrogen used for soil fertilization in region $i$ (see Table 1 )

Straw produced in regions should not all be removed from the fields. One part must be left on the field for the wind and water erosion control and one part of straw is used for bedding and feeding of livestock. The total amount of wheat straw required for soil protection depends on the soil texture and field slope. Coarse soil textures require large quantities of residue for control of wind erosion, and quantities needed for water erosion protection increase with the field slope. Straw needed for soil protection in the regions (expressed in $\mathrm{t}$ ) will be obtained as:

$S_{\mathrm{PW}(i)}=\mathrm{SCP}_{(i)} \times C_{\mathrm{A}(i)}$

where $\mathrm{SCP}_{(i)}$ represents the straw cover required for soil protection in region $i(\mathrm{t} / \mathrm{ha})$ (see Table 1$)$ and $C_{\mathrm{A}(i)}$ the cultivated area of wheat in region $i$ (ha).

Straw required for bedding and feeding of livestock varies from region to region and mainly depends on the duration of winter season and the number of cattle in the particular region. In regions with a large number of cattle this residue can be even higher than the potential of wheat straw in the region. Because of that these regions need to import straw from other regions which have high production of straw and small number of cattle. Requirements of wheat straw for feeding and bedding of livestock in the region $i$ (expressed in $\mathrm{t}$ ) will be obtained as: 
Table 2

Croatian state owned forest parameters [52].

\begin{tabular}{|c|c|c|c|c|}
\hline \multirow[t]{2}{*}{ Counties } & Forest area and forest land & Wood stock & Yearly growth & Yearly felling \\
\hline & 1000 ha & $1000 \mathrm{~m}^{3}$ & $1000 \mathrm{~m}^{3}$ & $1000 \mathrm{~m}^{3}$ \\
\hline Zagreb county & 62 & 15,000 & 400 & 272 \\
\hline Sisak-Moslavina & 151 & 36,700 & 1100 & 686 \\
\hline Karlovac county & 111 & 23,800 & 566 & 470 \\
\hline Koprivnica-Križevci & 42 & 11,650 & 305 & 265 \\
\hline Bjelovar-Bilogora & 86 & 24,200 & 635 & 500 \\
\hline Primorje-Gorski Kotar & 170 & 35,450 & 682 & 605 \\
\hline Lika-Senj & 306 & 44,920 & 1050 & 680 \\
\hline Virovitica-Podravina & 64 & 18,140 & 520 & 400 \\
\hline Požega-Slavonija & 78 & 16,660 & 450 & 290 \\
\hline Brod-Posavina & 53 & 13,680 & 380 & 300 \\
\hline Osijek-Baranja & 114 & 23,000 & 770 & 620 \\
\hline Vukovar-Syrmia & 69 & 20,240 & 545 & 450 \\
\hline Total "Hrvatske Šume" d.o.o. & 2020 & 302,420 & 7960 & 5800 \\
\hline
\end{tabular}

$S_{\mathrm{RL}(i)}=\mathrm{SLP}_{(i)} \times N_{\mathrm{C}(i)}$

where $\operatorname{SLP}_{(i)}$ represents the straw used for livestock production in region $i$ (t/cattle) (see Table 1 ) and $N_{\mathrm{C}(i)}$ the number of cattle in the region $i$.
Technical available potential of straw is obtained after subtracting the current quantities of straw needed for soil protection and for feeding and bedding of livestock in the region from the total production of wheat straw in region. In some regions this potential can be even lower than zero due to small production of wheat and

Table 3

Croatian cereals parameters for a period of 4 years (2002-2006) [58].

\begin{tabular}{|c|c|c|c|c|c|c|c|}
\hline \multirow[t]{2}{*}{ Counties } & & \multicolumn{3}{|l|}{ Wheat } & \multicolumn{3}{|l|}{ Corn } \\
\hline & & Cultivated area, ha & Production, $\mathrm{t}$ & Yield, t/ha & Cultivated area, ha & Production, t & Yield, t/ha \\
\hline \multirow[t]{3}{*}{ Total Croatia } & Avg. & 190,382 & 750,946 & 3.97 & 357,278 & $2,053,043$ & 5.86 \\
\hline & Max. & 233,611 & 988,175 & 4.58 & 407,455 & $2,501,774$ & 6.92 \\
\hline & Min. & 146,411 & 601,748 & 2.96 & 296,521 & $1,569,150$ & 3.86 \\
\hline \multirow[t]{3}{*}{ Zagreb county } & Avg. & 8916 & 27,216 & 3.16 & 31,760 & 149,846 & 4.92 \\
\hline & Max. & 13,929 & 45,967 & 3.67 & 39,522 & 211,441 & 5.90 \\
\hline & Min. & 4830 & 17,726 & 2.36 & 20,619 & 106,319 & 2.72 \\
\hline \multirow[t]{3}{*}{ Sisak-Moslavina } & Avg. & 5693 & 18,609 & 3.32 & 24,404 & 130,232 & 5.39 \\
\hline & Max. & 8978 & 32,679 & 3.70 & 25,793 & 153,525 & 6.51 \\
\hline & Min. & 2954 & 5444 & 2.35 & 22,822 & 92,339 & 3.58 \\
\hline \multirow[t]{3}{*}{ Varaždin } & Avg. & 4864 & 17,070 & 3.60 & 19,241 & 93,520 & 5.08 \\
\hline & Max. & 6317 & 23,625 & 4.29 & 22,627 & 108,600 & 6.64 \\
\hline & Min. & 3309 & 12,576 & 2.56 & 15,576 & 63,185 & 2.82 \\
\hline \multirow[t]{3}{*}{ Koprivnica-Križevci } & Avg. & 11,731 & 41,803 & 3.65 & 33,669 & 193,181 & 5.82 \\
\hline & Max. & 14,331 & 53,886 & 4.27 & 36,759 & 231,531 & 7.13 \\
\hline & Min. & 8693 & 34,076 & 2.63 & 29,367 & 142,625 & 3.88 \\
\hline \multirow[t]{3}{*}{ Bjelovar-Bilogora } & Avg. & 10,417 & 31,599 & 3.17 & 35,215 & 220,695 & 6.23 \\
\hline & Max. & 15,407 & 47,916 & 4.28 & 38,375 & 282,442 & 7.44 \\
\hline & Min. & 7112 & 23,927 & 2.05 & 33,387 & 143,906 & 4.21 \\
\hline \multirow[t]{3}{*}{ Virovitica-Podravina } & Avg. & 18,063 & 73,716 & 4.03 & 28,248 & 165,572 & 5.89 \\
\hline & Max. & 21,577 & 96,882 & 4.56 & 31,908 & 197,631 & 6.82 \\
\hline & Min. & 13,394 & 51,566 & 3.21 & 24,220 & 136,356 & 4.53 \\
\hline \multirow[t]{3}{*}{ Požega-Slavonija } & Avg. & 9242 & 37,202 & 4.05 & 12,908 & 80,803 & 6.24 \\
\hline & Max. & 11,254 & 50,079 & 4.46 & 13,834 & 102,783 & 7.43 \\
\hline & Min. & 7640 & 32,012 & 3.11 & 11,379 & 58,152 & 4.53 \\
\hline \multirow[t]{3}{*}{ Brod-Posavina } & Avg. & 12,238 & 47,207 & 3.85 & 21,597 & 128,731 & 6.07 \\
\hline & Max. & 14,698 & 59,527 & 4.17 & 25,702 & 165,006 & 7.16 \\
\hline & Min. & 10,586 & 36,789 & 3.13 & 17,613 & 96,381 & 3.98 \\
\hline \multirow[t]{3}{*}{ Osijek-Baranja } & Avg. & 54,038 & 237,067 & 4.36 & 63,942 & 401,530 & 6.37 \\
\hline & Max. & 60,171 & 293,034 & 5.01 & 73,554 & 517,512 & 7.34 \\
\hline & Min. & 47,469 & 174,534 & 3.28 & 55,197 & 311,134 & 4.23 \\
\hline \multirow[t]{3}{*}{ Vukovar-Syrmia } & Avg. & 34,415 & 154,500 & 4.49 & 38,352 & 270,261 & 7.16 \\
\hline & Max. & 38,138 & 184,590 & 4.97 & 49,070 & 376,369 & 8.38 \\
\hline & Min. & 28,562 & 122,642 & 3.50 & 26,990 & 230,093 & 5.15 \\
\hline \multirow[t]{3}{*}{ Međimurje } & Avg. & 5473 & 22,586 & 4.20 & 15,556 & 101,089 & 6.64 \\
\hline & Max. & 6971 & 31,161 & 4.56 & 17,994 & 123,799 & 7.96 \\
\hline & Min. & 4062 & 18,524 & 3.19 & 12,964 & 72,022 & 4.14 \\
\hline
\end{tabular}


Table 4

Characteristics of different types of biomass in Croatia.

\begin{tabular}{|c|c|c|c|c|c|c|}
\hline & Wheat straw & Ref. & Corn stover & Ref. & Forest residues & Ref. \\
\hline Straw (stover) to grain ratio $[-]$ & 1.6 & {$[48,62]$} & 0.8 & {$[48,62]$} & - & \\
\hline Straw cover required for soil protection [ $\mathrm{t} / \mathrm{ha}$ ] & 1.5 & {$[59,62]$} & - & & - & \\
\hline Biomass for livestock production [t/cattle] & 0.6 & {$[60,62]$} & - & & - & \\
\hline Mechanisation losses in the collecting process [\%] & - & & 20 & {$[48,61,62]$} & - & \\
\hline Soil protection factor $[\%]$ & - & & 50 & {$[48,59,61]$} & - & \\
\hline Forest residue factor [\%] & - & & - & - & 12 & {$[52,63]$} \\
\hline Lower heating value of biomass $[\mathrm{GJ} / \mathrm{t}]$ & 13.74 & {$[62]$} & 14.7 & [62] & 8.5 & {$[62]$} \\
\hline Humidity of biomass [\%] & 20 & [62] & 20 & [62] & 50 & {$[52,62]$} \\
\hline
\end{tabular}

large number of cattle in the region. This means that wheat straw needs to be imported in the region. Technical available potential of wheat straw in the region $i$ (expressed in $\mathrm{t}$ ) will be obtained as

$E_{\mathrm{PW}(i)}=T_{\mathrm{WS}(i)}-S_{\mathrm{PW}(i)}-S_{\mathrm{RL}(i)}$

where $T_{\mathrm{WS}(i)}$ represents the total wheat straw production in region $i$ $(\mathrm{t}), S_{\mathrm{PW}(i)}$ the straw needed for soil protection in region $i(\mathrm{t})$ and $S_{\mathrm{RL}(i)}$ the straw requirements for feeding and bedding of livestock in the region $i(\mathrm{t})$.

\subsubsection{Agricultural residual - corn stover}

Corn stover is an agricultural residue defined as the portions of the corn plant aside from the corn kernels that remain on the soil surface following grain harvest. Same as with the wheat straw, total quantity of the corn stover, generated during the grain harvest, is not possible to find in statistic yearbook and because of that total potential of corn stover needs to be calculated using corn stover to grain ratio. Total production of the corn stover in the region $i$ (expressed in $\mathrm{t}$ ) will be obtained as:

$T_{\mathrm{CS}(i)}=C_{\mathrm{P}(i)} \times \mathrm{STGR}_{C(i)}$

where $C_{\mathrm{P}(i)}$ represents the corn production in the region $i(\mathrm{t})$ and STGR $_{C(i)}$ the corn stover to grain ratio, whose value mainly depends on grain humidity in the time of harvesting (see Table 1)

It is not possible to collect all corn stover from the field because of the losses generated during the process of harvesting and

Table 5

Technical available potential of corn stover in Croatian counties.

\begin{tabular}{|c|c|c|c|c|c|}
\hline Counties & & $\begin{array}{l}\text { Total potential of } \\
\text { corn stover, [t] }\end{array}$ & $\begin{array}{l}\text { Corn stover needed for } \\
\text { soil protection, }[\mathrm{t}]\end{array}$ & $\begin{array}{l}\text { Harvesting and collection } \\
\text { losses, [t] }\end{array}$ & $\begin{array}{l}\text { Technical available potential } \\
\text { of corn stover, [t] }\end{array}$ \\
\hline \multirow[t]{3}{*}{ Total Croatia } & Avg & $1,642,434$ & 821,217 & 328,487 & 492,730 \\
\hline & Max & $2,001,419$ & $1,000,710$ & 400,284 & 600,426 \\
\hline & Min & $1,255,320$ & 627,660 & 251,064 & 376,596 \\
\hline \multirow[t]{3}{*}{ Zagreb county } & Avg & 119,876 & 59,938 & 23,975 & 35,963 \\
\hline & Max & 169,153 & 84,576 & 33,831 & 50,746 \\
\hline & Min & 85,055 & 42,528 & 17,011 & 25,517 \\
\hline \multirow[t]{3}{*}{ Sisak-Moslavina } & Avg & 104,186 & 52,093 & 20,837 & 31,256 \\
\hline & Max & 122,820 & 61,410 & 24,564 & 36,846 \\
\hline & Min & 73,871 & 36,936 & 14,774 & 22,161 \\
\hline \multirow[t]{3}{*}{ Varaždin } & Avg & 74,816 & 37,408 & 14,963 & 22,445 \\
\hline & Max & 86,880 & 43,440 & 17,376 & 26,064 \\
\hline & Min & 50,548 & 25,274 & 10,110 & 15,164 \\
\hline \multirow[t]{3}{*}{ Koprivnica-Križevci } & Avg & 154,544 & 77,272 & 30,909 & 46,363 \\
\hline & Max & 185,225 & 92,612 & 37,045 & 55,567 \\
\hline & Min & 114,100 & 57,050 & 22,820 & 34,230 \\
\hline \multirow[t]{3}{*}{ Bjelovar-Bilogora } & Avg & 176,556 & 88,278 & 35,311 & 52,967 \\
\hline & Max & 225,954 & 112,977 & 45,191 & 67,786 \\
\hline & Min & 115,125 & 57,562 & 23,025 & 34,537 \\
\hline \multirow[t]{3}{*}{ Virovitica-Podravina } & Avg & 132,458 & 66,229 & 26,492 & 39,737 \\
\hline & Max & 158,105 & 79,052 & 31,621 & 47,431 \\
\hline & Min & 109,085 & 54,542 & 21,817 & 32,725 \\
\hline \multirow[t]{3}{*}{ Požega-Slavonija } & Avg & 64,642 & 32,321 & 12,928 & 19,393 \\
\hline & Max & 82,226 & 41,113 & 16,445 & 24,668 \\
\hline & Min & 46,522 & 23,261 & 9304 & 13,956 \\
\hline \multirow[t]{3}{*}{ Brod-Posavina } & Avg & 102,985 & 51,492 & 20,597 & 30,895 \\
\hline & Max & 132,005 & 66,002 & 26,401 & 39,601 \\
\hline & Min & 77,105 & 38,552 & 15,421 & 23,131 \\
\hline \multirow[t]{3}{*}{ Osijek-Baranja } & Avg & 321,224 & 160,612 & 64,245 & 96,367 \\
\hline & Max & 414,010 & 207,005 & 82,802 & 124,203 \\
\hline & Min & 248,907 & 124,454 & 49,781 & 74,672 \\
\hline \multirow[t]{3}{*}{ Vukovar-Syrmia } & Avg & 216,209 & 108,104 & 43,242 & 64,863 \\
\hline & Max & 301,095 & 150,548 & 60,219 & 90,329 \\
\hline & Min & 184,074 & 92,037 & 36,815 & 55,222 \\
\hline \multirow[t]{3}{*}{ Međimurje } & Avg & 80,871 & 40,435 & 16,174 & 24,261 \\
\hline & Max & 99,039 & 49,520 & 19,808 & 29,712 \\
\hline & Min & 57,618 & 28,809 & 11,524 & 17,285 \\
\hline
\end{tabular}


Table 6

Technical available potential of wheat straw in Croatian counties.

\begin{tabular}{|c|c|c|c|c|c|}
\hline Counties & & $\begin{array}{l}\text { Total potential } \\
\text { of wheat straw, [t] }\end{array}$ & $\begin{array}{l}\text { Wheat straw needed } \\
\text { for soil protection, [t] }\end{array}$ & $\begin{array}{l}\text { Wheat straw needed for feeding } \\
\text { and bedding of livestock, }[\mathrm{t}]\end{array}$ & $\begin{array}{l}\text { Technical available potential } \\
\text { of wheat straw, [t] }\end{array}$ \\
\hline \multirow[t]{3}{*}{ Total Croatia } & Avg & $1,201,513$ & 285,573 & 293,188 & 622,752 \\
\hline & Max & $1,581,080$ & 350,417 & & 937,476 \\
\hline & Min & 962,797 & 219,617 & & 449,993 \\
\hline \multirow[t]{3}{*}{ Zagreb county } & Avg & 43,545 & 13,373 & 32,786 & - \\
\hline & Max & 73,547 & 20,894 & & 19,867 \\
\hline & Min & 28,362 & 7245 & & - \\
\hline \multirow[t]{3}{*}{ Sisak-Moslavina } & Avg & 29,774 & 8539 & 17,305 & 3930 \\
\hline & Max & 52,286 & 13,467 & & 21,514 \\
\hline & Min & 8710 & 4431 & & - \\
\hline \multirow[t]{3}{*}{ Varaždin } & Avg & 27,312 & 7296 & 13,876 & 6140 \\
\hline & Max & 37,800 & 9476 & & 14,449 \\
\hline & Min & 20,122 & 4964 & & 1283 \\
\hline \multirow[t]{3}{*}{ Koprivnica-Križevci } & Avg & 66,885 & 17,597 & 47,222 & 2066 \\
\hline & Max & 86,218 & 21,497 & & 17,499 \\
\hline & Min & 54,522 & 13,040 & & - \\
\hline \multirow[t]{3}{*}{ Bjelovar-Bilogora } & Avg & 50,559 & 15,625 & 43,448 & - \\
\hline & Max & 76,666 & 23,111 & & 10,107 \\
\hline & Min & 38,283 & 10,668 & & - \\
\hline \multirow[t]{3}{*}{ Virovitica-Podravina } & Avg & 117,945 & 27,095 & 11,551 & 79,299 \\
\hline & Max & 155,011 & 32,366 & & 111,095 \\
\hline & Min & 82,506 & 20,091 & & 50,863 \\
\hline \multirow[t]{3}{*}{ Požega-Slavonija } & Avg & 59,523 & 13,863 & 7141 & 38,519 \\
\hline & Max & 80,126 & 16,881 & & 56,104 \\
\hline & Min & 51,219 & 11,460 & & 32,618 \\
\hline \multirow[t]{3}{*}{ Brod-Posavina } & Avg & 75,530 & 18,356 & 10,210 & 46,964 \\
\hline & Max & 95,243 & 22,047 & & 62,986 \\
\hline & Min & 58,862 & 15,879 & & 32,773 \\
\hline \multirow[t]{3}{*}{ Osijek-Baranja } & Avg & 379,307 & 81,057 & 30,806 & 267,443 \\
\hline & Max & 468,854 & 90,257 & & 347,792 \\
\hline & Min & 279,254 & 71,204 & & 177,245 \\
\hline \multirow[t]{3}{*}{ Vukovar-Syrmia } & Avg & 247,200 & 51,623 & 15,802 & 179,775 \\
\hline & Max & 295,344 & 57,207 & & 222,335 \\
\hline & Min & 196,227 & 42,843 & & 137,583 \\
\hline \multirow[t]{3}{*}{ Međimurje } & Avg & 36,138 & 8209 & 10,250 & 17,679 \\
\hline & Max & 49,858 & 10,457 & & 29,151 \\
\hline & Min & 29,638 & 6093 & & 13,295 \\
\hline
\end{tabular}

collecting. These losses mainly depend on the mechanisation used in the harvesting and collecting process $[48,49]$. Total amount of corn stover which cannot be removed from the field (expressed in t) will be obtained as:

$U_{\mathrm{CS}(i)}=T_{\mathrm{CS}(i)} \times M_{\mathrm{L}}$

where $T_{\mathrm{CS}(i)}$ represents the total potential of corn stover which is produced on the field in the region $i(\mathrm{t})$ and $M_{\mathrm{L}}$ the mechanisation losses (\%), which mainly depend on the field machinery used (see Table 1).

Corn stover residues left on the field protect soil from water and wind erosion and increase soil organic carbon (SOC) dynamics. For higher corn yield and lower soil erosion, greater presence of stover is needed. Therefore, adequate residue cover must be left on the field to prevent erosion losses and to increase total SOC [56]. Total amount of corn stover required for soil protection in the region $i$ (expressed in $\mathrm{t}$ ) will be obtained as:

$S_{\mathrm{PC}(i)}=T_{\mathrm{CS}(i)} \times S_{\mathrm{PP}(i)}$

where $T_{\mathrm{CS}(i)}$ represent the total amount of corn stover produced on the field in region $i(\mathrm{t})$, and $S_{\mathrm{PP}(i)}$ the soil protection factor in the region $i(\%)$.
Technical available potential of corn stover is obtained after subtracting the quantities of stover needed for soil protection and losses due to collecting and harvesting process from the total production of corn stover in region. These mechanisation losses in the process of harvesting and collecting of corn stover are higher than the losses in collecting of straw. Main reason for this is the specific shape of the corn stover. Technical available potential of corn stover in the region $i$ (expressed in $\mathrm{t}$ ) will be obtained as:

$E_{\mathrm{PC}(i)}=T_{\mathrm{CS}(i)}-S_{\mathrm{PC}(i)}-U_{\mathrm{CS}(i)}$

where $T_{\mathrm{CS}(i)}$ represents the total corn stover production in region $i$ $(\mathrm{t}), S_{\mathrm{PC}(i)}$ the corn stover required for soil protection in region $i(\mathrm{t})$ and $U_{\mathrm{CS}(i)}$ the uncollected corn stover from the field in the region $i$ $(\mathrm{t})$.

\subsubsection{Forestry residues}

Biomass usable for energy purpose is produced during silvicultural operations aimed at producing firewood and industrial wood and from sustainable sawlog harvest. These residues represent the most economical and technical fraction to be used in a bioenergy system. The methodology followed is based on the current national yearly felling and biomass fraction, but only for tree branches over $7 \mathrm{~cm}$ in diameter. Technical available potential 


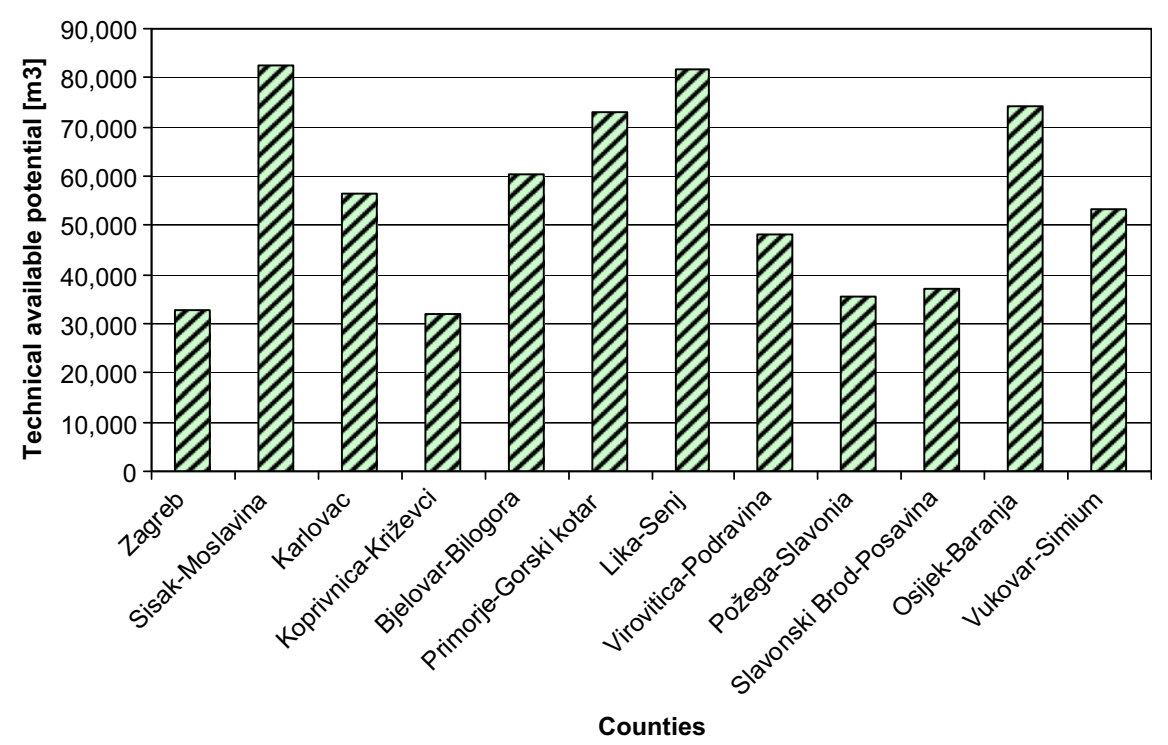

Fig. 2. Technical available potential of forestry residues in Croatian counties.

Table 7

Energy potential of agricultural residuals in Croatian counties.

\begin{tabular}{|c|c|c|c|}
\hline Counties & & $\begin{array}{l}\text { Energy potential } \\
\text { of corn stover, } 1000 \mathrm{GJ}\end{array}$ & $\begin{array}{l}\text { Energy potential of } \\
\text { wheat straw, } 1000 \mathrm{GJ}\end{array}$ \\
\hline \multirow[t]{3}{*}{ Total Croatia } & Avg & 7243 & 8557 \\
\hline & Max & 8826 & 12,881 \\
\hline & Min & 5536 & 6183 \\
\hline \multirow[t]{3}{*}{ Zagreb county } & Avg & 529 & - \\
\hline & Max & 746 & 273 \\
\hline & Min & 375 & - \\
\hline \multirow[t]{3}{*}{ Sisak-Moslavina } & Avg & 459 & 54 \\
\hline & Max & 542 & 296 \\
\hline & Min & 326 & - \\
\hline \multirow[t]{3}{*}{ Varaždin } & Avg & 330 & 84 \\
\hline & Max & 383 & 199 \\
\hline & Min & 223 & 18 \\
\hline \multirow[t]{3}{*}{ Koprivnica-Križevci } & Avg & 682 & 28 \\
\hline & Max & 817 & 240 \\
\hline & Min & 503 & - \\
\hline \multirow[t]{3}{*}{ Bjelovar-Bilogora } & Avg & 779 & - \\
\hline & Max & 996 & 139 \\
\hline & Min & 508 & - \\
\hline \multirow[t]{3}{*}{ Virovitica-Podravina } & Avg & 584 & 1090 \\
\hline & Max & 697 & 1526 \\
\hline & Min & 481 & 699 \\
\hline \multirow[t]{3}{*}{ Požega-Slavonija } & Avg & 285 & 529 \\
\hline & Max & 363 & 771 \\
\hline & Min & 205 & 448 \\
\hline \multirow[t]{3}{*}{ Brod-Posavina } & Avg & 454 & 645 \\
\hline & Max & 582 & 865 \\
\hline & Min & 340 & 450 \\
\hline \multirow[t]{3}{*}{ Osijek-Baranja } & Avg & 1417 & 3675 \\
\hline & Max & 1826 & 4779 \\
\hline & Min & 1098 & 2435 \\
\hline \multirow[t]{3}{*}{ Vukovar-Syrmia } & Avg & 953 & 2470 \\
\hline & Max & 1328 & 3055 \\
\hline & Min & 812 & 1890 \\
\hline \multirow[t]{3}{*}{ Međimurje } & Avg & 357 & 243 \\
\hline & Max & 437 & 401 \\
\hline & Min & 254 & 183 \\
\hline
\end{tabular}

of forestry residues in the region $i$ (expressed in $\mathrm{m}^{3}$ ) will be obtained as:

$E_{\mathrm{PF}(i)}=Y_{\mathrm{F}(i)} \times F_{\mathrm{R}}$

where $Y_{\mathrm{F}}$ represents the yearly felling of the forest in the region $i$ $\left(\mathrm{m}^{3}\right)$ and $F_{\mathrm{R}}$ the forestry residues factor (\%), the amount of the total mass of the tree which can be used for the energy purpose (see Table 1).

\subsection{Energy potential}

The assessment of the biomass energy potential is based on the total biomass potential and the respective lower heating value of each biomass type available for energy purposes. Lower heating value is different for each type of biomass, its value depends on the chemical structure of biomass, contents of moisture in the biomass and content of the hydrogen in the biomass. Energy potential for different types of biomass (expressed in $1000 \mathrm{GJ}$ ) will be obtained as:

$B_{\mathrm{ep}(n)}=E_{\mathrm{p}(n)} \times \operatorname{LHV}_{(n)}$

where $E_{\mathrm{p}(n)}$ represents the technical available potential of biomass type $n$ (expressed in tons) and $\operatorname{LHV}_{(n)}$ the lower heating value of biomass (expressed in GJ/ton) (see Table 1), which depends on humidity and type of wood.

\subsection{Cost of biomass at the power plant location}

Cost of biomass at the power plant location depends on the cost of biomass at the forest road or agricultural field, transportation cost, distance between biomass location and plant location and on the size of the energy plant. The main impact on the cost of the biomass has biomass feedstock costs and transport distance of the biomass which mainly depends on the size of the power plants and on the available biomass in the regions. Cost of biomass at the power plant locations (expressed in $€ /$ tons) will be obtained as:

$G_{\mathrm{C}}=\sum_{i=1}^{n} \frac{\left[C_{\mathrm{B}}+\left(T_{\mathrm{P}} \times U_{i}\right)\right] \times K_{\mathrm{B} i}}{P_{\mathrm{B}}}$ 


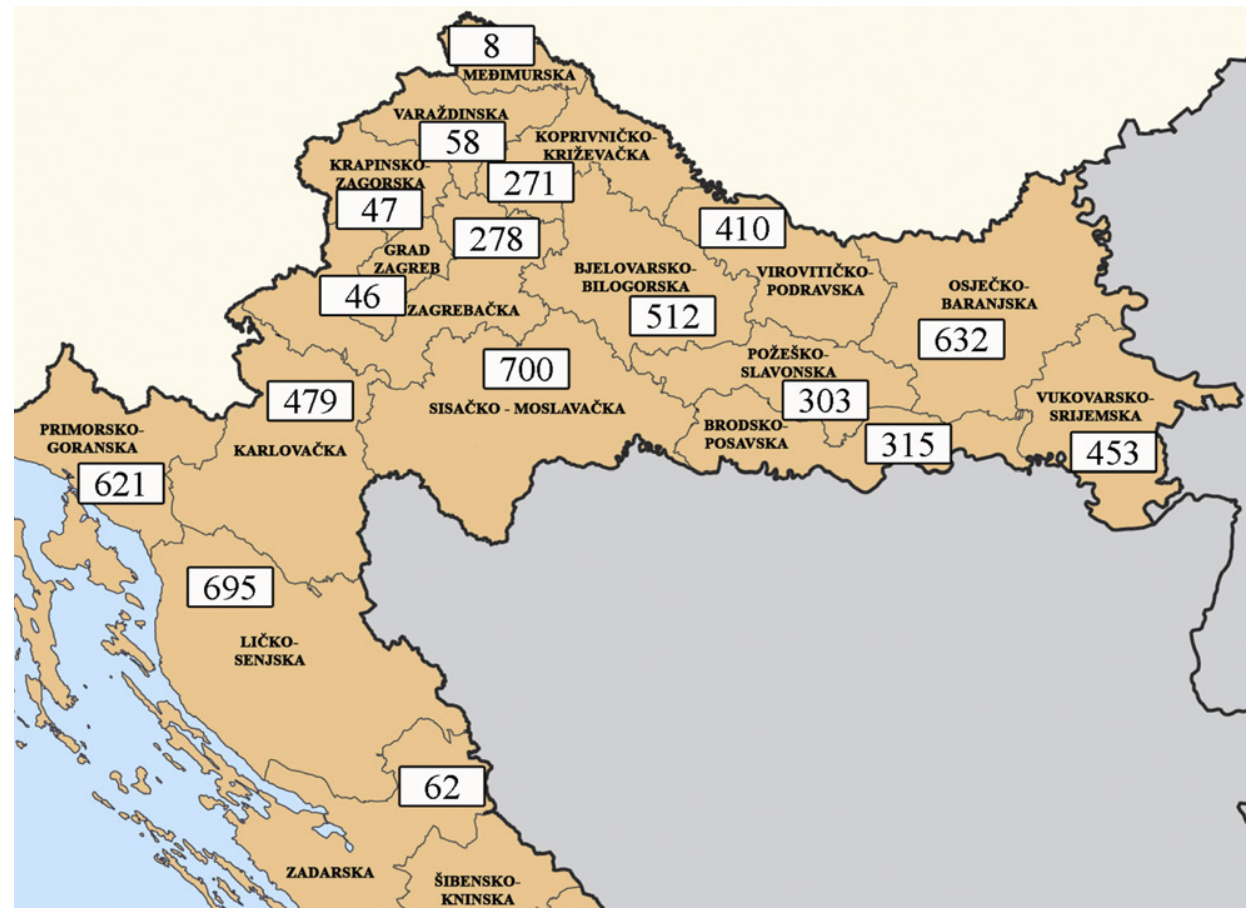

Fig. 3. Energy potential of forest residues in Croatian counties [1000 GJ].

- $G_{\mathrm{C}}$ : Average price of biomass at the plant location ( $€ /$ ton)

- $C_{\mathrm{B}}$ : Biomass feedstock costs $(€ /$ ton $)$

- $T_{\mathrm{P}}$ : Biomass specific transport costs $(€ /$ ton $/ \mathrm{km})$

- $U_{i}$ : Distance between administrative center of the region and the plant location $(\mathrm{km})$

- $K_{\mathrm{Bi}}$ : The total amount of biomass delivered from the region $i$ (ton)

- $P_{\mathrm{B}}$ : Annual fuel consumption of the power plant (ton)

Methodology for determining the distance $\left(U_{i}\right)$ between the plant location $\left(P_{\mathrm{L}}\right)$ and center of the region $\left(\mathrm{C}_{\mathrm{R} i}\right)$ is illustrated in Fig. 1. In Fig. 1 distance between plant location and center of the region is illustrated as a straight line but for more precise results, Geographical Information System (GIS) is recommended to be used.

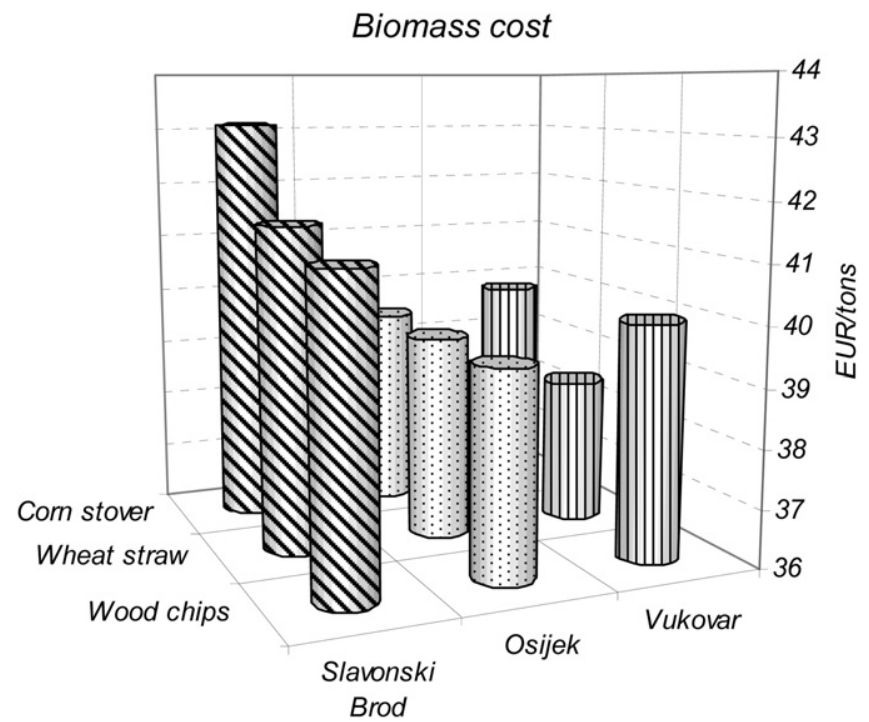

Fig. 4. Cost of biomass at the selected location for the power plants with the capacity of $100,000 \mathrm{t} /$ year and biomass transport cost of $0.1 € / \mathrm{t} / \mathrm{km}$.

\subsection{Upper-level price of the biomass and electricity generation cost}

Methodology for the evaluation of upper-level price of the biomass and economic prospect of biomass-fired power plants has been performed based on electricity generation cost and feed-in tariffs. Upper-level of the biomass price will be obtained as:

$\mathrm{COB}_{\max }=\left[\mathrm{FIT}-\left(\frac{\mathrm{C}_{\mathrm{I}}}{\mathrm{LF}} \times \frac{i \times(1+1)^{n}}{(1+i)^{n}-1}-C_{\mathrm{OM}}\right)\right] \times \mathrm{LHV} \times \eta_{\mathrm{PP}-\mathrm{E}} \times \frac{1000}{3.6}$

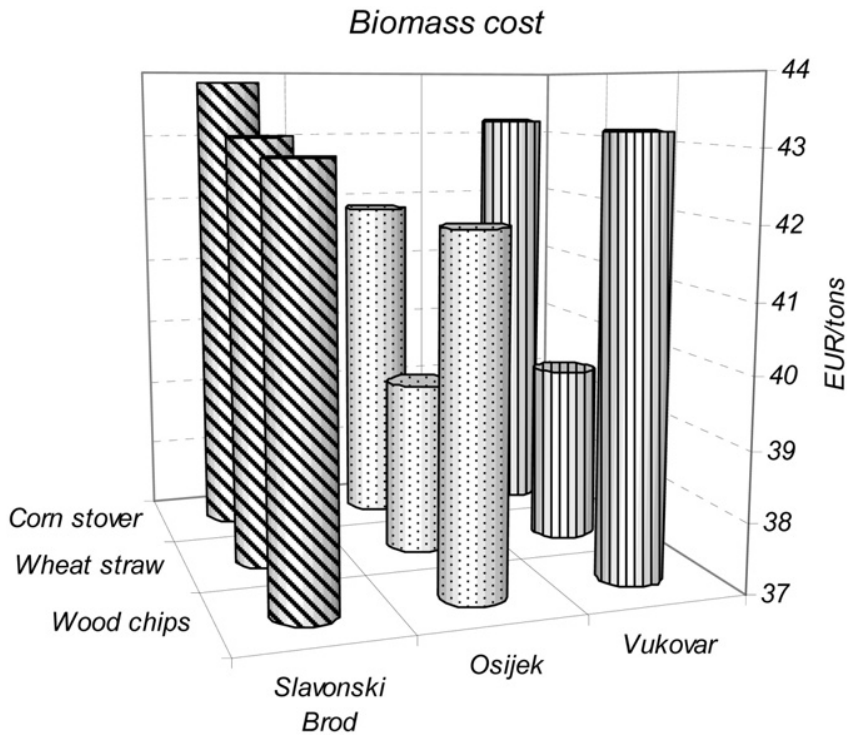

Fig. 5. Cost of biomass at the selected location for the power plants with the capacity of $200,000 \mathrm{t} /$ year and biomass transport cost of $0.1 € / \mathrm{t} / \mathrm{km}$. 


\section{Biomass cost}

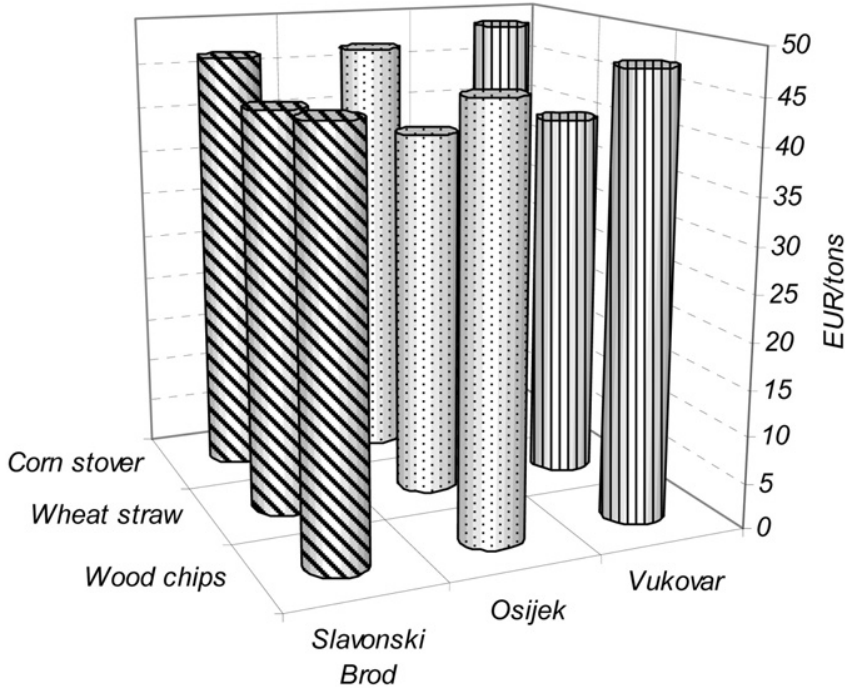

Fig. 6. Cost of biomass at the selected location for the power plants with the capacity of $300,000 \mathrm{t} /$ year and biomass transport cost of $0.1 € / \mathrm{t} / \mathrm{km}$.

where $\mathrm{COB}_{\max }$ represents the maximal cost of the biomass at the power plant location during the whole year $(€ / \mathrm{t})$, FIT the feed-in tariffs for produced electricity from biomass-fired power plant $(€ / \mathrm{kWh}), C_{\mathrm{I}}$ the specific investment cost $(€ / \mathrm{kWh})$, LF the annual load factor (h/a), $i$ the discount rate (\%), $n$ the economic life time of power plant, $C_{0 \& \mathrm{M}}$ the specific operation and maintenance cost of the power plant, LHV the lower heating value of the biomass $(\mathrm{GJ} / \mathrm{t})$ and $\eta_{\text {PP-E }}$ the net electric efficiency of the energy plant (-).

Model for the assessment of electricity generation costs from the biomass has been proposed. The cost of generated electricity depends on the operating and maintenance cost, investment cost, cost of the biomass at the agricultural field or forest road, specific transport cost and on the transport distance of the biomass. Electricity generation cost will be obtained as:

$$
\begin{aligned}
C_{\mathrm{E}}= & C_{\mathrm{OM}}+\left(\frac{C_{\mathrm{I}}}{\mathrm{LF}} \times \frac{i \times(1+1)^{n}}{(1+i)^{n}-1}\right)+\left[\left(\frac{3.6}{1000} \times \frac{1}{\mathrm{LHV} \times \eta_{\mathrm{PP}-\mathrm{E}}}\right)\right. \\
& \left.\times\left(F_{\mathrm{S}}+T_{\mathrm{R}} \times D\right)\right]
\end{aligned}
$$

where $C_{\mathrm{E}}$ represents the electricity generation cost $(€ / \mathrm{kWh}), F_{\mathrm{S}}$ the cost of the biomass at the agricultural field or forest road $(€ / t), T_{R}$ the biomass specific transport cost $(€ /$ ton $/ \mathrm{km} /)$ and $D$ the distance to plant $(\mathrm{km})$.

Table 8

\begin{tabular}{|c|c|c|c|c|c|c|}
\hline$P\left(\mathrm{MW}_{\mathrm{e}}\right)$ & $C_{\mathrm{I}}(€ / \mathrm{kW})$ & $\begin{array}{l}C_{\mathrm{O} \& \mathrm{M}} \\
(\mathrm{c} \in / \mathrm{kWh})\end{array}$ & $\eta_{\text {PP-E }}(\%)$ & $\mathrm{LF}(\mathrm{h} / \mathrm{a})$ & $\operatorname{LHV}(\mathrm{GJ} / \mathrm{t})$ & $\begin{array}{l}\text { Biomass } \\
\text { price }(€ / t)\end{array}$ \\
\hline \multicolumn{7}{|c|}{ Forest residues (FR) } \\
\hline $1 \mathrm{MW}$ & 4100 & 1.54 & 29 & 7971.6 & 8.5 & 36.9 \\
\hline $10 \mathrm{MW}$ & 1300 & 0.56 & 35 & 7884 & 8.5 & 40 \\
\hline \multicolumn{7}{|c|}{ Wheat straw (WS) } \\
\hline $1 \mathrm{MW}$ & 4200 & 2.11 & 29 & 7971.6 & 13.74 & 36.4 \\
\hline $10 \mathrm{MW}$ & 1700 & 1 & 29 & 7884 & 13.74 & 38.5 \\
\hline \multicolumn{7}{|c|}{ Corn stover (CS) } \\
\hline $1 \mathrm{MW}$ & 4400 & 2.21 & 27 & 7971.6 & 14.7 & 36.1 \\
\hline $10 \mathrm{MW}$ & 1850 & 1.01 & 25 & 7884 & 14.7 & 39.85 \\
\hline
\end{tabular}

Characteristics of the biomass-fired power plants $[7,62,66,67]$.
Upper-level price of the biomass

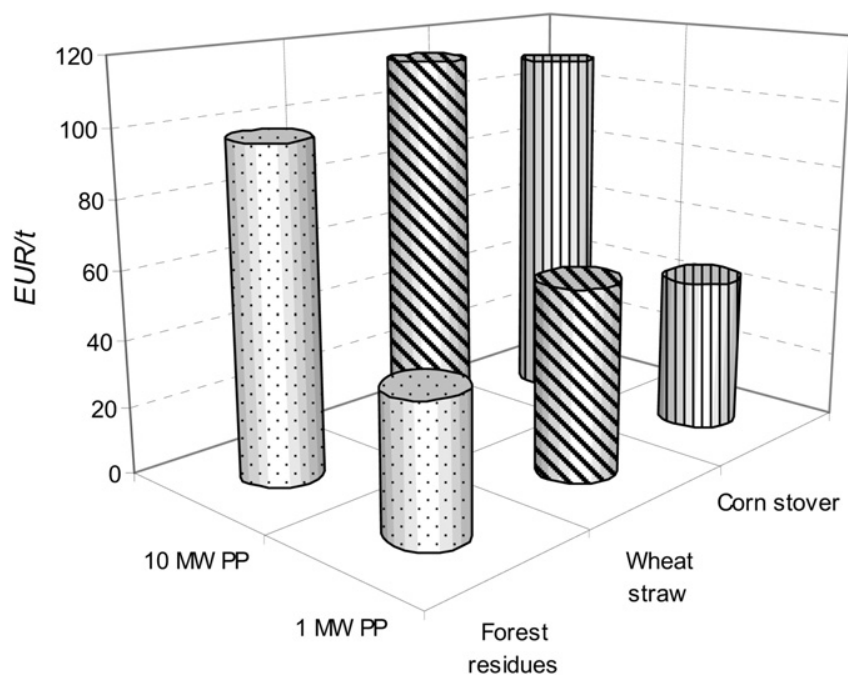

Fig. 7. Upper-level price of the biomass for different sizes of the power plants and biomass types in Croatia.

\section{Study area: Croatia}

\subsection{Production of cereals and forest potential in Croatia}

Land surface of the Republic of Croatia spreads over a total of $56,542 \mathrm{~km}^{2}$, out of which $42 \%$ is under forests, $19 \%$ is available for cultivation, $19 \%$ is limitedly suitable for cultivation, and $14 \%$ is not available for cultivation and can be used for cultivation of energy crops [57]. Republic of Croatia is divided into counties, primary territorial subdivisions. There are total 21 counties, counting in the City of Zagreb which has status equal to a county. Croatia produces more than $2.8 \mathrm{Mt}$ of wheat and corn grain annually and cuts over 4.5 million cubic meters of state owned forest $[52,58]$. Planed yearly felling in the period of 2006-2015 is around 5.8 million cubic meters of tree and for the period 2016-2025 planed yearly felling will be between 5.8 and 6.4 million cubic meters [52]. In Table 2

\section{Electricity generation costs}

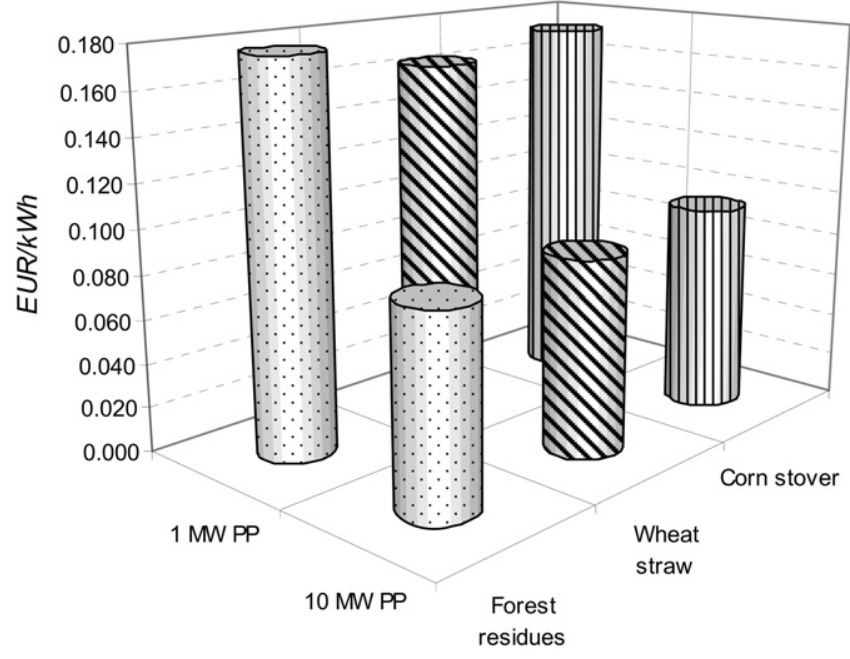

Fig. 8. Electricity generation costs for the biomass-fired power plants. 


\section{Electricity generation costs}

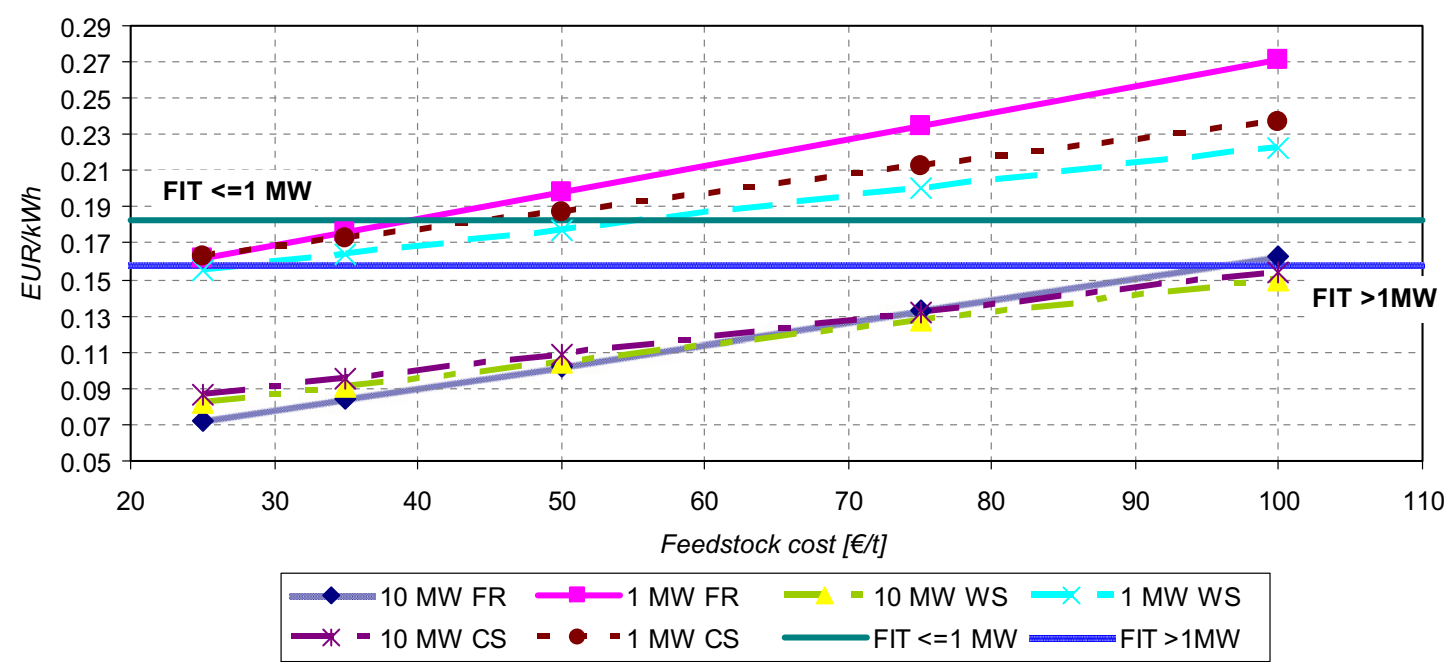

Fig. 9. Influence of the feedstock cost on the electricity generation cost, $T_{\mathrm{R}}=0.1 € / \mathrm{t} / \mathrm{km}, D=50 \mathrm{~km}$ for $10 \mathrm{MW} \mathrm{PP}$ and $D=15 \mathrm{~km}$ for $1 \mathrm{MW}$ PP.

characteristic data for state owned forests in Croatian counties for period 2006-2015, is presented. Total cultivated area, production of cereals and yield in Croatian counties, which have reasonable potential are shown in Table 3.

\subsection{Technical available potential of biomass}

The availability of biomass from the forest and main crops in Croatia has been evaluated. The potential of biomass in counties was calculated by using appropriate value from Table 4 .

Agricultural biomass has been identified and calculated for two categories, wheat straw and corn stover. Traditionally agricultural counties in the east part of Croatia, Osijek-Baranja and VukovarSyrmia, have the highest potential of the agricultural residues. To calculate technical available potential of wheat straw, number of cattle in counties has been used. These numbers vary from county to county and in case of Croatia this data has been obtained from [64]. Technical available potential of wheat straw in Croatia ranges from the maximum $930 \mathrm{kt} \mathrm{year}^{-1}$ to the minimum $450 \mathrm{kt} \mathrm{year}^{-1}$ and corn stover ranges from the maximum of $600 \mathrm{kt} \mathrm{year}^{-1}$ to the minimum of $370 \mathrm{ktyear}^{-1}$. Technical available potential of corn stover is presented in Table 5 and potential of wheat straw is presented in Table 6 .

Calculated potential of forestry residues in Croatia is over 700,000 cubic meters. Counties with the large quantities of forestry residues are Sisak-Moslavina and Lika-Senj, over 80,000 cubic meters. Technical available potential of forestry residues in Croatian counties is shown in Fig. 2.

\subsection{Energy potential of biomass}

The energy potential of the biomass in Croatia was estimated by using LHV for different types of biomass. Characteristics of various biomass types, in Croatia, have been reported in Table 4. Highest energy potential has the east part of Croatia and minimal potential have counties in the south part of Croatia so that potential can be

\section{Electricity generation costs}

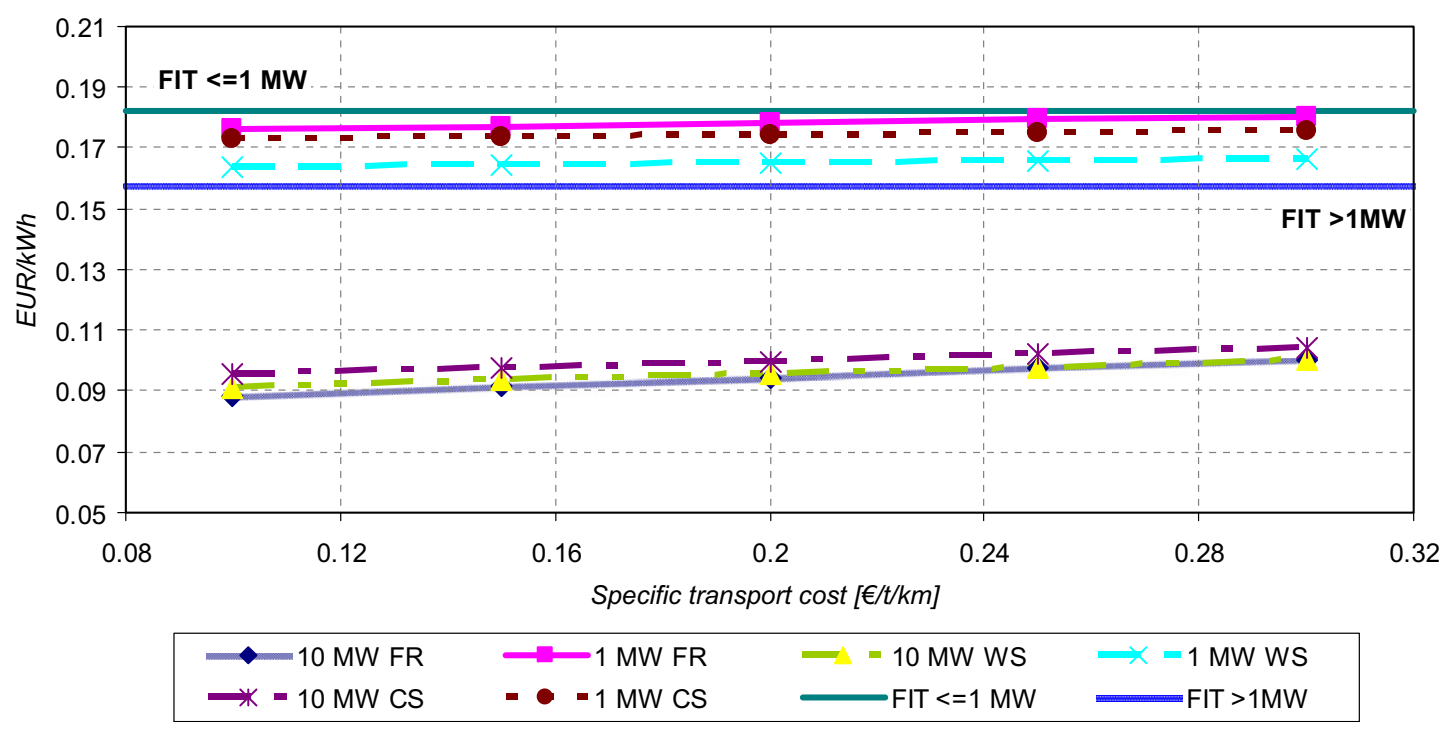

Fig. 10. Influence of the specific transport cost on the electricity generation cost, $F_{\mathrm{S}}=35 € / \mathrm{t}, D=50 \mathrm{~km}$ for $10 \mathrm{MW}$ PP and $D=15 \mathrm{~km}$ for $1 \mathrm{MW}$ PP. 


\section{Electricity generation costs}

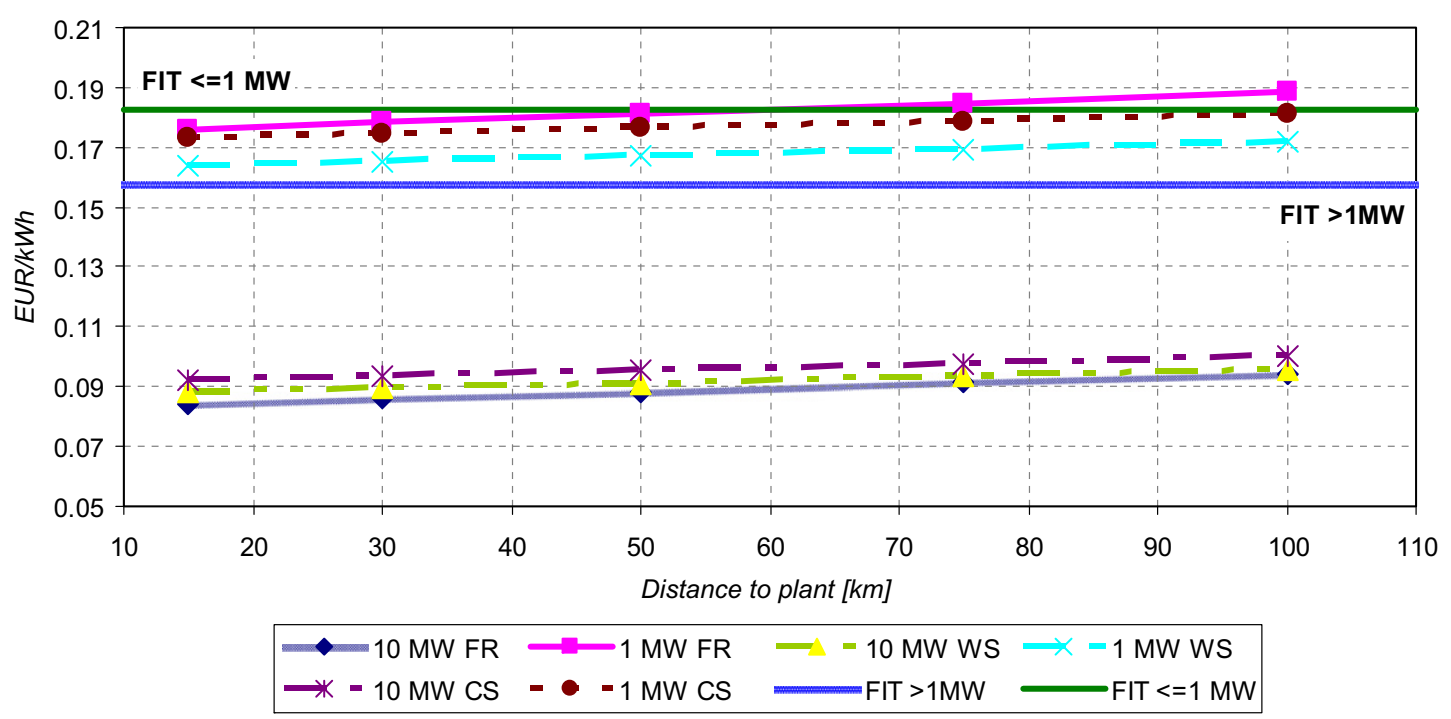

Fig. 11. Influence of the collecting radius of the biomass on the electricity generation cost, $T_{\mathrm{R}}=0.1 € / \mathrm{t} / \mathrm{km}, F_{\mathrm{S}}=35 € / \mathrm{t} / \mathrm{km}$.

disregarded. Energy potential of agricultural residuals in Croatia is presented in Table 7.

Energy potential of forestry residues is calculated for all counties in Croatia and the potential is presented in Fig. 3. Highest potential has Sisak-Moslavina County, over $700,000 \mathrm{GJ}$ and total energy potential of forestry residues in Croatia state owned forests is over 5.9 PJ. For transforming technical available potential of forestry residues from cubic meters to tons, density of $1 \mathrm{t} / \mathrm{m}^{3}$ was used [52].

\subsection{Cost of biomass at the power plant location}

The cost of the biomass at the location of the power plant has been calculated based on the input data from Section 3.2 and Eq. (11). Transport distance of biomass has been evaluated using methodology from Section 2.3. For purpose of this study road distance from the plant location and center of regions (counties) was obtained from the existing road maps in Croatia. Transport cost of biomass of $0.1 € / \mathrm{t} / \mathrm{km} \mathrm{[65]}$ and the cost of biomass of $35 € / \mathrm{t}$ $[52,62]$ on road, have been used in the calculation of the biomass costs. Also, costs of biomass have been calculated for different sizes of power plants ranging between $100,000 \mathrm{t}$ and $300,000 \mathrm{t}$. Calculated results for different types of biomass, size and location of the power plants (selected by taking into account biomass potential of counties, development of the cities and polycentric development of the Republic of Croatia) have been presented in Figs. 4-6.

The comparison of the calculated biomass cost shows that the cost generally increases with the increase of the plant capacity. The illustration also shows that selected locations Osijek and Vukovar have lower calculated price of biomass compared to Slavonski Brod. Calculated costs for the biomass-fired power plant in Vukovar are in range between $38.5 € / \mathrm{t}$ and $40 € / \mathrm{t}$. These costs are calculated for the biomass-fired plant with the capacity of 100,000 t/years. Also, the illustration shows that the most suitable location for the power plants with the capacity of $200,000 \mathrm{t} /$ year and $300,000 \mathrm{t} / \mathrm{year}$ is Osijek, followed by Vukovar and Slavonski Brod.

\subsection{Upper-level price of the biomass and electricity generation cost}

To determinate upper-level price of the biomass at the plant location, Eq. (12) has been used and appropriated value from
Table 8. Feed-in tariffs for electricity delivered from biomass-fired power plants are determined with respect to the power plant size. For the power plants with installed power up to and including $1 \mathrm{MW}$, feed-in tariff for 2010, in Croatia, is $1.3312 \mathrm{HRK} / \mathrm{kWh}(0.1824$ $€ / \mathrm{kWh}$ ) and for power plants with installed power over $1 \mathrm{MW}$, feed-in tariff is $1.1537 \mathrm{HRK} / \mathrm{kWh}(0.158 € / \mathrm{kWh})$ [68]. The discount rate of $18 \%$ and the economic life time of 12 years were used to determinate the maximal costs of the biomass in Croatia [7,62]. Calculated results for different size of power plants and biomass types have been presented in Fig. 7.

Calculated results show that the upper-level of the biomass price for the power plants with installed power of $10 \mathrm{MW}$ is 97.58 $€ / \mathrm{t}$ for forestry residues, $114.06 € / \mathrm{t}$ for wheat straw and $109.12 € / \mathrm{t}$ for corn stover fired power plants. For power plants with installed power of $1 \mathrm{MW}$, upper-level price of forestry residues is $40.83 € / t$, for wheat straw $56.85 € / \mathrm{t}$ and for corn stover this price is $46.06 € / \mathrm{t}$.

The electricity generation costs from the biomass-fired plants have been calculated by using Eq. (13) and appropriated value from Table 8 and Section 3.4. Input data in Table 8 is for biomass-fired plants with grate combustion and steam turbines. Calculated results for different size of power plants and for three types of biomass have been presented in Fig. 8 .

Calculated results show that electricity generation cost for $10 \mathrm{MW}$ power plant which uses forestry residues as fuel is 0.088 $€ / \mathrm{kWh}$, for wheat straw fuel this cost is $0.09 € / \mathrm{kWh}$ and for corn stover fuel electricity generation cost is $0.095 € / \mathrm{kWh}$. For power plants with the installed power of $1 \mathrm{MW}$ which use forestry residues as fuel, electricity generation cost is $0.177 € / \mathrm{kWh}$, for wheat straw fuel $0.164 € / \mathrm{kWh}$ and for corn stover fuel this cost is $0.173 € / \mathrm{kWh}$. The comparison of the calculated electricity generation costs shows that the best solution for $10 \mathrm{MW}$ power plants is forestry residues as fuel and for $1 \mathrm{MW}$ power plants it is wheat straw.

Since the size of the power plant, cost of the biomass at the agricultural field or forest road, biomass specific transport cost and the biomass transport distance have high influence on the electricity generation cost, a sensitive analysis has been performed. For the analysis, Eq. (13) has been used. The results have been presented in Figs. 9-11.

On the illustrations, calculated generation costs are compared with feed-in tariffs for biomass-fired power plants in Croatia. The 
analysis of the presented data shows that most of the biomass-fired power plants would be profitable. Also analysis shows that the highest impact on the electricity generation costs has the price of the biomass feedstock and in case when these costs are very high, electricity generation costs from the biomass-fired power plants are higher than feed-in tariffs.

\section{Conclusion}

In this paper, a methodology for economic evaluation of the biomass potential and the cost of the biomass at the plant location has been presented. The methodology has been applied to Croatia and with this methodology we have assessed which type of the biomass is most suitable for use in the biomass-fired power plants in Croatia. From the agricultural and forest statistical data it was possible to estimate the technical and energy potential for each type of the biomass. Results show that high quantities of the agricultural and forestry residues exist in Croatia. Average quantity of wheat straw which can be removed from the field is $600 \mathrm{kt}$ and corn stover $490 \mathrm{kt}$. Available potential of forestry residues calculated in this study is 690,000 cubic meters. Average energy potential of forestry residues is $5.9 \mathrm{PJ}$, wheat straw $8.5 \mathrm{PJ}$ and corn stover 7.2 PJ.

An analysis performed for the assessment of the biomass cost at the energy plant location in Croatia, indicate that these costs range between $38.5 € / \mathrm{t}$ and $48.7 € / \mathrm{t}$. Analysis was performed for different biomass types, size and locations of the power plants. Also, analysis performed for the assessment of the upper-level price of the biomass on the basis of the resulting cost of the electricity, the biomass-fired plants could even pay up to $100 € / \mathrm{t}$ (10 MW power plants) for the biomass bought from outside suppliers, if the payback tariff of the electricity sold to the grid equal to the feed-in tariffs. The methodology applied for the estimation of the biomass cost didn't take into consideration competing uses of the biomass with other sectors and therefore, future studies should be focused on that issue.

\section{References}

[1] Gustavsson L, Holmberg J, Dornburg V, Sathre R, Eggers T, Mahapatra K, et al. Using biomass for climate change mitigation and oil use reduction. Energy Policy 2007;35(11):5671-91.

[2] Perry S, Klemeš J, Bulatov I. Integrating waste and renewable energy to reduce the carbon footprint of locally integrated energy sectors. Energy 2008;33 (10):1489-97.

[3] Henrik L. Renewable energy strategies for sustainable development. Energy 2007;32(6). 912-9.

[4] Demirbas MF, Balat M, Balat H. Potential contribution of biomass to the sustainable energy development. Energy Conversion and Management 2009;50(7):1746-60.

[5] Liu W, Lund H, Mathiesen BV, Zhang X. Potential of renewable energy systems in China. Applied Energy 2011;88(2):518-25.

[6] Ayres RU, Turton H, Casten T. Energy efficiency, sustainability and economic growth. Energy 2007;32(5):634-48.

[7] Lončar D, Duić N, Bogdan Ž. An analysis of the legal and market framework for the cogeneration sector in Croatia. Energy 2009;34(2):134-43.

[8] Heinimö J, Junginger M. Production and trading of biomass for energy - an overview of the global status. Biomass and Bioenergy 2009;33(9):1310-20.

[9] Fowler P, Krajačić G, Lončar D, Duić N. Modeling the energy potential of biomass - H2RES. International Journal of Hydrogen Energy 2009;34 (16):7027-40.

[10] Al-Kassir A, Gañán-Gómez J, Mohamad AA, Cuerda-Correa EM. A study of energy production from Cork residues: sawdust, sandpaper dust and triturated wood. Energy 2010;35(1):382-6.

[11] Lior N. Energy resources and use: the present situation and possible paths to the future. Energy 2008;33(6):842-57.

[12] Openshaw K. Biomass energy: employment generation and its contribution to poverty alleviation. Biomass and Bioenergy 2010;34(3):365-78.

[13] Hillebrand B, Buttermann HG, Behringer JM, Bleuel M. The expansion of renewable energies and employment effects in Germany. Energy Policy 2006;34(18):3484-94.
[14] Groscurth HM, de Almeida A, Bauen A, Costa FB, Ericson SO, Giegrich J, et al. Total costs and benefits of biomass in selected regions of the European Union. Energy 2000;25(11):1081-95.

[15] Solino M. External benefits of biomass-e in Spain: an economic valuation. Bioresource Technology 2010;101(6):1992-7.

[16] Schneider DR, Duić N, Bogdan Ž. Mapping the potential for decentralized energy generation based on renewable energy sources in the Republic of Croatia. Energy 2007;32(9):1731-44.

[17] Thornley P, Rogers J, Huang Y. Quantification of employment from biomass power plants. Renewable Energy 2008;33(8):1922-7.

[18] Bryan AB, Ward J, Hobbs T. An assessment of the economic and environmental potential of biomass production in an agricultural region. Land Use Policy 2008;25(4):533-49.

[19] Jingura RM, Matengaifa R. The potential for energy production from crop residues in Zimbabwe. Biomass and Bioenergy 2008;32(12):1287-92.

[20] Shuit SH, Tan KT, Lee KT, Kamaruddin AH. Oil Palm biomass as a sustainable energy source: a Malaysian case study. Energy 2009;34(9):1225-35.

[21] Li X, Huang Y, Gong J, Zhang X. A study of the development of bio-energy resources and the status of eco-society China. Energy 2010;35(11): 4451-6.

[22] Viana H, Cohen BW, Lopes D, Aranha J. Assessment of forest biomass for use as energy. GIS-based analysis of geographical availability and locations of woodfired power plants in Portugal. Applied Energy 2010;87(8):2551-60.

[23] MacFarlane WD. Potential availability of urban wood biomass in Michigan: implications for energy production, carbon sequestration and sustainable forest management in the U.S.A. Biomass and Bioenergy 2009;33(4): $628-34$.

[24] Kinoshita T, Inoue K, Iwao K, Kagemoto H, Yamagata Y. A spatial evaluation of forest biomass usage using GIS. Applied Energy 2009;86(1):1-8.

[25] Lopez-Rodriguez F, Atanet CP, Blazquez FC, Celma AR. Spatial assessment of the bioenergy potential of forest residues in the western province of Spain, Caceres. Biomass and Bioenergy 2009;33(10):1358-66.

[26] Fernandes U, Costa M. Potential of biomass residues for energy production and utilization in a region of Portugal. Biomass and Bioenergy 2010;34(5): 661-6.

[27] Vasco H, Costa M. Quantification and use of forest biomass residues in Maputo province, Mozambique. Biomass and Bioenergy 2009;33(9):1221-8.

[28] Beccali M, Columba P, D'Alberti V, Franzitta V. Assessment of bioenergy potential in Sicily: a GIS-based support methodology. Biomass and Bioenergy 2009;33(1):79-87.

[29] Steubing B, Zah R, Waeger P, Ludwig C. Bioenergy in Switzerland: assessing the domestic sustainable biomass potential. Renewable and Sustainable Energy Reviews 2010;14(6):2256-65.

[30] Leweandowski I, Weger J, van Hooijdonk A, Havlickova K, van Dam J, Faaij A The potential biomass for energy production in the Czech Republic. Biomass and Bioenergy 2006;30(5):405-21.

[31] Karaj S, Rehl T, Leis H, Müller J. Analysis of biomass residues potential for electrical energy generation in Albania. Renewable and Sustainable Energy Reviews 2010;14(1):493-9.

[32] Van den Broek R, Teeuwisse S, Healion K, Kent T, van Wijk A, Faaij A, et al. Potentials for electricity production from wood in Ireland. Energy 2001;26 (11):991-1013.

[33] Hoogwijk M, Faaij A, Van den Broek R, Berndes G, Gielen D, Turkenburg W. Exploration of the ranges of the global potential of biomass for energy. Biomass and Bioenergy 2003;25(2):119-33.

[34] De Wit M, Faaij A. European biomass resource potential and cost. Biomass and Bioenergy 2010;34(2):188-202.

[35] Singh J, Panesar BS, Sharma SK. Energy potential through agricultural biomass using geographical information system - a case study of Punjab. Biomass and Bioenergy 2008;32(4):301-7.

[36] Voivontas D, Assimacopoulos D, Koukios EG. Assessment of biomass potential for power production: a GIS based method. Biomass and Bioenergy 2001;20 (2):101-12.

[37] Jack MW. Scaling laws and technology development strategies for biorefineries and bioenergy plants. Bioresource Technology 2009;100(24):6324-30.

[38] Frombo F, Minciardi R, Robba M, Sacile R. A decision support system for planning biomass-based Energy production. Energy 2009;34(3):362-9.

[39] Van Dyken S, Bakken BH, Skjelbred HI. Linear mixed-integer models for biomass supply chains with transport, storage and processing. Energy 2010;35(3):1338-50.

[40] Ravula PP, Grisso RD, Cundiff JS. Cotton logistics as a model for a biomass transportation system. Biomass and Bioenergy 2008;32(4):314-25.

[41] Junginger M, Faaij A, Van den Broek R, Koopmans A, Hulscher W. Fuel supply strategies for large-scale bio-energy projects in developing countries. Electricity generation from agricultural and forest residues in Northeastern Thailand. Biomass and Bioenergy 2001;21(4):259-75.

[42] Möller B, Nielsen PS. Analysing transport costs of Danish forest wood chip resources by means of continuous cost surface. Biomass and Bioenergy 2007;31(5):291-8.

[43] Duić N, Krajačić G, Carvalho MG. RenewIslands methodology for sustainable energy and resource planning for islands. Renewable and Sustainable Energy Reviews 2008;12(4):1032-62.

[44] Krajačić G, Duić N, Carvalho MG. $\mathrm{H}_{2}$ RES, energy planning tool for island energy systems - the case of the Island of Mljet. International Journal of Hydrogen Energy 2009;34(16):7015-26. 
[45] Krajačić G, Mathiesen B, Duić N, Carvalho MG. The role of energy storages in energy independent Croatia. In: Conference proceedings, 18. forum: Dan energije u Hrvatskoj, Zagreb, Croatia; 2009 [in Croatian].

[46] Schneider DR, Duić N, Bogdan Ž, Ban M, Grubor B, Borislav S, et al. Mapping the potential for decentralised energy generation based on RES in Western Balkan. Thermal Science 2007:11(3):7-26.

[47] Schneider DR, Duić N, Bogdan Ž, Ban M, Grubor B, Stefanović P, et al. Map of deg potential in $\mathrm{WB}$, deliverable 1 . Advanced decentralized energy generation systems in Western Balkans (ADEG), EC, FP6; 2005.

[48] Domac J. Program korištenja energije biomase i otpada. Prethodni rezultati i buduće aktivnosti. Zagreb, travanj: Energetski institut "Hrvoje Požar"; 1998 [in Croatian].

[49] Sokhansanj S, Turhollow A, Cushman J, Cundiff J. Engineering aspects of collecting corn stover for bioenergy. Biomass and Bioenergy 2002;23(5): 347-55.

[50] Pordesimo LO, Edens WC, Sokhansanj S. Distribution of aboveground biomass in corn stover. Biomass and Bioenergy 2004;26(4):337-43.

[51] Kline R. Estimating crop residue cover for soil erosion control. Soil factsheet. http://www.agf.gov.bc.ca/resmgmt/publist/600series/641220-1.pdf

[52] Molc J, Slunjski M, Sučić Ž. Iskorak Hrvatskih šuma d.o.o. 2. Hrvatski dani biomase. Gospić: Golubinjak; 2007 [in Croatian].

[53] Using straw as farm heating fuel. http://www.pami.ca/pdfs/reports reasearch_updates/using_straw_as_a_farm_heating_fuel_719.pdf.

[54] Sokhansanj S, Mani S, Stumborg M, Samson R, Fanton J. Production and distribution of cereal straw on the Canadian Prairies. Canadian Biosystems Engineering 2006;48:3.39-46.

[55] Petrolia DR. The economics of harvesting and transporting corn stover for conversion to fuel ethanol: a case study for Minnesota. Biomass and Bioenergy 2008;32(7):603-12.

[56] Mann L, Tolbert V, Cushman J. Potential environmental effects of corn (Zea mays L) stover removal with emphasis on soil organic matter and erosion. Agriculture, Ecosystems \& Environment 2002;89(3):149-66.
[57] Tomić F, Krička T, Matić S. Raspoložive poljoprivredne površine I mogućnost šuma za proizvodnju biogoriva u Hrvatskoj. Sumarski list 2008;132 (7-8):323-30 [in Croatian].

[58] Production of some important crops. In: Croatian statistical yearbook, Zagreb 2007;39(2):656-9 [in Croatian]

[59] Domac J, Tomšić Ž. Proizvodnja energije iz slame i kukuruzovine u Istočnoj Hrvatskoj. Energija 1997;46(6):383-8 [in Croatian].

[60] Knežević M, Perčulija G, Bošnjak K, Leto J, Vranić M. tehnološko-tehničke osnove sustava krava tele. Stočarstvo 2005:59(6):443-50 [in Croatian].

[61] Centar za energetsku učinkovitost i obnovljive izvore energije. http://www. energo-consult.hr/oie-obnovljivi-izvori [accessed 05.08.10, in Croatian].

[62] Duić N, Lončar D, Cosić B. Analiza potencijala izgradnje energetskih postrojenja loženih biomasom i odabir optimalnih lokacija. Sveučilište u Zagrebu - Fakultet strojarstva i brodogradnje; 2009 [in Croatian].

[63] Grupa autora. Studija izvodljivosti - Komercijalno korištenja drvnog ostatka u centralnoj Bosni I Hercegovini kao projekat oporavka i ekonomskog razvoja regije. REZ Regionalna razvojna agencija za regiju Centralna BiH; 2006 [in Croatian].

[64] Državni zavod za statistiku. http://www.dzs.hr/ [accessed 05.08.10, in Croatian].

[65] Edwards RAH, Šuri M, Huld TA, Dallemand JF. GIS-based assessment of cereal straw energy resource in the European Union. Cereals straw resources for bioenergy in the European Union. Expert Consultation. 2006 October 18-19. Pamplona, Spain.

[66] Kirjavainen M, Sipilä K, Savola T, Salomón M, Alakangas E. Small-scale biomass CHP technologies. Situation in Finland, Denmark and Sweden. OPET Report 12. Espoo (FI): VTT Processes (FI); 2004 April. Contract no. NNE5/2002/ 52: OPET CHP/DH Cluster.

[67] Danish Energy Agency (DK). Technology data for energy plants, http://www ens.dk/Documents/Netboghandel\%20-\%20publikationer/2010/Technology_ data_for_energy_plants.pdf; 2010 June.

[68] Hrvatski operator tržišta energije. http://www.hrote.hr/ [accessed 05.08.10, in Croatian]. 